\title{
Practicing and Transmitting Traditional Music within the Southern Khmer Community of Vietnam in International Integration Context
}

\author{
Pham Tiet Khanh \\ Tra Vinh University, Tra Vinh province, Vietnam \\ Email:ptkhanh@tvu.edu.vn
}

DOI: 10.26821/IJSRC.9.7.2021.9732

\begin{abstract}
The article studies the reality of practicing and transmitting traditional music within the Southern Khmer community in Vietnam - review from globalization context. This study was conducted in 2018 and 2019, at 10 southern provinces/cities of Vietnam (surveying, interviewing 222 people, artisans and artists) to learn and evaluate the activities of practicing and transmitting traditional music of Southern Khmer of Vietnam. The method of Ethnographic field-visit was mainly used. Research results showed that traditional music genres are still practiced and transmitted in cultural activities of Khmer people in the South of Vietnam, including 3/7 genres of folk songs: ritual music, Chom-Rieng-Cha-Pay, lullaby and 3/12 traditional orchestras: Five-tone orchestra (Pin Peat), Kh'se orchestra and Chhay-Yam orchestra. Traditional music is mainly transmitted by "word of mouth" form which is attached with artisans and artists; the transmission forms of collecting, researching, and introducing have been implemented but are still limited. Based on the results, recommendations are proposed for preserving and promoting traditional musical heritage of the Southern Khmer people of Vietnam in the current context of globalization.
\end{abstract}

Keywords: traditional music, Southern Khmer community of Vietnam, globalization context.

\section{INTRODUCTION}

The South of Vietnam is home to many ethnic groups living together for a long time. Among ethnic minorities in the South of Vietnam, the population of Khmer ethnic group account for the largest number. According to the survey results of the population and housing census in 2019, there were 1,319,652 [1] Khmer people mostly inhabiting in the South of Vietnam, especially in the Mekong Delta.

According to Dao Chuong, the Southern Khmer traditional music has been created very early and persistently by previous generations, which has been transmitted until now (...). After periods of time with ups and downs under different stages of development and transformation from traditional to modern instruments, the Khmer traditional music has taken a process of interference and selection in order to adapt to the psychology, emotions, and personality of the Southern Khmer. Nowadays, it is regarded as a valuable heritage of the nation [2].

It is believed that the Southern Khmer traditional music has made remarkable contributions to the national cultural identity and the connection among individuals, between individual and the community as well as among ethnic groups in the South of Vietnam. Therefore, it has been considered important spiritual activities related to religions, beliefs, cultural and daily activities of the Southern Khmer.

However, in the current context of integration and globalization, the Southern Khmer's traditional music is facing many difficulties and challenges. Firstly, Son Ngoc Hoang claimed that 'the domination of foreign cultural and musical products and Western music' [3, p.16] as well as new and attractive musical programs on social networking sites has partly lessen the importance of 
Volume 9 Issue 7 July 2021

traditional music in the Southern Khmer's community activities. Secondly, policies on economic, social and cultural development in the context of globalization have, to some extents, influenced the Southern Khmer traditional music. The Southern Khmer traditional music was created in the context of countryside and the Theravada Buddhist pagoda, in which the tangible and intangible cultural values of the Southern Khmer have been preserved. However, the young generations in the Southern Khmer community who are expected to practice and transmit the traditional music have gradually left the countryside for urban areas and industrial zones to earn their livings. This phenomenon causes the lack of young people who are expected to inherit and transmit the music of the nation. Meanwhile, many artisans and artists who directly practice the traditional music have to give up their passion for their livings. People are always under the needs of physical life satisfaction. Therefore, the need for livelihood of artisans' families is considered an urgent issue. As a result, the role of the traditional music in the Southern Khmer's cultural life has not been as important as before. Especially, there will be the risk of losing good artists and traditional songs.

Based on the above-mentioned practical problems the article aims to explore the practicing and transmitting of traditional music within the Southern Khmer community of Vietnam - review from globalization context. Based on the research results, recommendations are proposed for preserving and promoting traditional musical heritage of the Southern Khmer people of Vietnam in the current context of globalization.

\section{LITERATURE REVIEW}

The theoretical framework on the Southern Khmer traditional music has been detailed in the research on "The national and international research on the Southern Khmer folk music" [4]. In particular, the national studies on the Southern Khmer folk music were divided into 4 major groups, including studies on the traditional music of Vietnam referring to the Southern Khmer folk music, studies on the Southern Khmer culture and art referring to issues of the Southern Khmer folk music, studies on the Southern Khmer folk music, and studies on achievements, reality and potential solutions for preserving and promoting values of the Southern Khmer folk music. Regarding international studies, a number of works implemented in Cambodia are reviewed. Such studies mainly focused on traditional arts of the Khmer in Cambodia, including music, dance and theatre. The most remarkable research on Cambodia traditional music was conducted and published in 2017 by Francesca Billeri. Through a case-study of Cambodian Living Arts (CLA), 'This paper examines the dynamics of the process of preservation and revival of these art forms which aims to promote and reconstruc the traditional music but, at the same time, this lead to the commercialization, westernization, "patronization" and de-contextualization of traditional music' [5, p.92]. Through the research, Francesca Billeri provided specific evidences on the practice of preserving and promoting the traditional music in the current context of Cambodia. Valuable experiences and controversial issues related to this process mentioned in Francesca Billeri's research could be considered an important theoretical framework for the current study on practicing and transmitting the Southern Khmer traditional music in Vietnam.

The research conducted by Pham Tiet Khanh and his associates published in the Scientific Journal of Tra Vinh University has determined the current practice of preserving and promoting the values of folk music of the Southern Khmer in terms of policies of the Party and State, methods and contents of preserving and promoting the values of folk music of the Southern Khmer. The article also identified achievements, limitations and the causes of those achievements and limitations in preserving and promoting the Southern Khmer folk music in recent years [6]. Based on such research results, the current study deeply explores traditional musical genres being practiced and transmitted in the cultural life of the Southern Khmer community as well as the impacts of the globalization context on this outstanding artistic heritage.

\section{RESEARCH METHODOLOGY}

With the aim of examining the practicing and transmitting of the Southern Khmer traditional music, this study utilized the Ethnographic fieldvisit method at 10 southern provinces/cities of Vietnam in which there are many Khmer people living. In addition, the study was carried out in some other places in Cambodia where there are activities related to preserving and promoting outstanding culture and arts such as Cultural Village (Siem Reap), the model of preserving and 
Volume 9 Issue 7 July 2021

promoting folk music at Cambodian Living Arts (Siem Reap), the model of preserving folk music at Angkor Wat complex (Siem Reap), the production of Khmer traditional musical instruments (Phnom Penh), the model of preserving folk culture and art at the National Museum of Cambodia (Phnom Penh). The Ethnographic field-visit was conducted in 2018 and 2019 on the targeted participants of people, artisans, artists, researchers, and managers. Thach $\mathrm{Mu} \mathrm{Ni}$ confirmed that 'there are many musical genres in Southern Khmer folk music, which has been preserved and promoted for a long time. These genres are formed and developed based on emotional needs, psychological and emotional developments and the needs of people's cultural and community activities' [7, p.41]. Southern Khmer music was generated and practiced in
The survey and interview were implemented on a group of 268 participants in the South of Vietnam and 20 others in Cambodia. The researcher used the SPSS software (version 22) for data analysis.

\section{RESULTS AND DISCUSSION}

\subsection{The reality of practicing the Southern Khmer traditional music}

association with religious activities, beliefs, folk rituals, working environment, and the living environment of Southern Khmer people. Based on the survey data collected from artisans and artists, Table 1 specifically states major cultural activities associated with the practice of Khmer Southern folk music.

Table 1. Genres of Southern Khmer traditional music practiced in cultural environment

\begin{tabular}{|c|c|c|c|c|}
\hline No. & GENRES & $\begin{array}{l}\text { PRACTICING } \\
\text { SPACES }\end{array}$ & PARTICIPANTS & SPECIFIC FORMS \\
\hline 1. & $\begin{array}{l}\text { Religious ritual } \\
\text { music }\end{array}$ & $\begin{array}{c}\text { Pagoda } \\
\text { Inside people's house }\end{array}$ & $\begin{array}{c}\text { Monks } \\
\text { Buddhists } \\
\text { People }\end{array}$ & $\begin{array}{l}\text { Buddha's birthday } \\
\text { celebration; consecration } \\
\text { ceremony of Buddha Statute; } \\
\text { praying for peace, praying } \\
\text { for salvation; launching rain- } \\
\text { retreat ceremony (chôl vôsa), } \\
\text { marking end of rain-retreat } \\
\text { ceremony (chênh vôsa); } \\
\text { robe-offering ceremony; } \\
\text { inauguration ceromony }\end{array}$ \\
\hline 2. & Ritual music & $\begin{array}{l}\text { On the field } \\
\text { Under the trees } \\
\text { People's house } \\
\text { Neakta temple } \\
\text { Phum, Soc } \\
\text { Sa la tien (the hall of } \\
\text { Khmer pagoda) }\end{array}$ & $\begin{array}{c}\text { Shamans } \\
\text { Householders } \\
\text { Persons related to } \\
\text { householder }\end{array}$ & $\begin{array}{l}\text { Neakta worshiping } \\
\text { ceremony, Arak worshiping } \\
\text { ceremony, moon worshiping } \\
\text { ceremony, worshiping the } \\
\text { ancestors of Ro bam, Du ke } \\
\text { and Yike theatre art. }\end{array}$ \\
\hline 3. & Festival music & $\begin{array}{c}\text { Pagoda } \\
\text { Phum, Soc } \\
\text { People's house } \\
\text { Cultural relic site } \\
\text { Museum }\end{array}$ & $\begin{array}{c}\text { Monks } \\
\text { Buddhists } \\
\text { People }\end{array}$ & $\begin{array}{l}\text { Raom vong, Saravan, Lam } \\
\text { leav, Rom kbach }\end{array}$ \\
\hline
\end{tabular}


iJournals: International Journal of Social Relevance \& Concern (IJSRC)

ISSN-2347-9698

Volume 9 Issue 7 July 2021

\begin{tabular}{|c|c|c|c|c|}
\hline & & $\begin{array}{c}\text { Grandstand/stage (Ngo } \\
\text { boat racing festival) }\end{array}$ & & \\
\hline 4. & Wedding music & $\begin{array}{c}\text { People's house } \\
\text { Outdoor }\end{array}$ & $\begin{array}{c}\text { Members of two } \\
\text { families } \\
\text { A Cha } \\
\text { People }\end{array}$ & \\
\hline 5. & Funeral music & $\begin{array}{c}\text { Inside people's house } \\
\text { Pagoda }\end{array}$ & $\begin{array}{c}\text { Monks } \\
\text { Buddhists } \\
\text { People }\end{array}$ & \\
\hline 6. & Mo-ho-ri & $\begin{array}{c}\text { Inside people's house } \\
\text { Pagoda } \\
\text { Stage } \\
\text { Art festivals }\end{array}$ & People & \\
\hline 7. & $\begin{array}{l}\text { Chhay-Yam } \\
\text { Drum Dance }\end{array}$ & $\begin{array}{c}\text { Pagoda } \\
\text { People's house } \\
\text { Places where the } \\
\text { festivals take place }\end{array}$ & $\begin{array}{c}\text { Performers/ } \\
\text { musicians } \\
\text { Monks } \\
\text { Buddhists } \\
\text { Peonle }\end{array}$ & \\
\hline 8. & Lullaby & Insid & Family members & \\
\hline 9. & $\begin{array}{l}\text { Dong-Dao } \\
\text { (children's } \\
\text { songs) }\end{array}$ & Outdoor & $\begin{array}{c}\text { Children } \\
\text { Teenagers } \\
\text { Elders }\end{array}$ & \\
\hline 10. & Chanty & $\begin{array}{c}\text { Inside people's house } \\
\text { Outdoor } \\
\text { Art festivals }\end{array}$ & $\begin{array}{c}\text { Teenagers } \\
\text { Artisans } \\
\text { Artists }\end{array}$ & \\
\hline 11. & Work songs & In working time & Working people & $\begin{array}{c}\text { Rice-planting songs, } \\
\text { Weaving songs... }\end{array}$ \\
\hline 12. & Action songs & In community activities & Working people & Starling bird, Pounding rice... \\
\hline 13. & A-day singing & Stage & $\begin{array}{c}\text { Artisans } \\
\text { Artists }\end{array}$ & \\
\hline
\end{tabular}


Volume 9 Issue 7 July 2021

\begin{tabular}{|c|c|c|c|c|}
\hline 14. & Pagoda & Artisans & \\
& $\begin{array}{c}\text { Chom-Rieng- } \\
\text { Cha-Pay }\end{array}$ & People's house & Artists & \\
& At home & people & \\
\hline 15. & $\begin{array}{c}\text { Edage } \\
\text { songs }\end{array}$ & Pagoda & Buddhists & \\
& Artists & \\
\hline
\end{tabular}

(Source: Synthesized from survey, interview results, 2019)

Table 1 shows that the spaces for practicing Southern Khmer traditional music is diverse and associated with the subject's living activities.

First, practicing Southern Khmer traditional music is attached with the Southern Buddhist pagodas where religious ceremonies and the most important festival activities of the Southern Khmer ethnic group are held such as Buddha's birthday ceremony, consecration ceremony of Buddha statute, praying for peace, praying for salvation, launching rain-retreat ceremony, marking end of rain-retreat ceremony, robe-offering ceremony; inauguration ceremony; Neakta temple or under ancient trees are places attached with folk religious activities such as worshiping Neakta and Arak god,

Second, Southern Khmer traditional music was formed and attached with the working, producing

\section{POUNDING RICE}

Ifyou pound rice, you shouldn't throw away the husk

The ancients said that, rice husks were stuffed to make bricks.

Brown rice that is not clean, also becomes white

Ten times ivory all thanks to your hands.

If you pound rice, you shouldn't throw away the bran

Bran is used to raise pigs for selling, easy to earn money.

Provided by: Ms. Son Thi Suong, 64 years old, Tra Vinh province

Collection time: 2018

Third, traditional music of the Southern Khmer is practiced in collective folk culture activities, connecting Phum, Soc in the occasion of traditional festivals of the Khmer ethnic group such as: Chol Chnam Thmay, Ok Om Bok, Ngo boat racing, Moon worshiping... Duong Hoang Loc and his associates identified, 'Coming to Phum, Soc of the Khmer people in the South during these holidays, the young and old Khmer rhythmically dance together with the sound of drums and the sound of five-tone music in the yard of the pagoda and the house. In that way, they together feel the collective spirit, traditional cultural values of the community, and the secular aspects of traditional festivals' [8]. The folk song 'Quiet and deserted Night' expresses the boy's sincere feelings for the girl and he wishes for a wedding with the offerings that imbue with 
traditional customs of the Khmer inhabiting in Southern Vietnam.

\title{
QUIET AND DESERTED NIGHT
}

\author{
At late quiet and desert night \\ I lie down and pray \\ Wish to see you. \\ In January of new year \\ I will ask you to marry \\ Marry you as my wife. \\ Here are pomelo, palmyra, coconut \\ Fabric for you to make new dress \\ Here are tobacco, betel and areca.
}

Ask you to be my wife, I don't let you wait long

Marriage, betel and areca according to custom.

Provided by: Mr. Huu Ut, 55 years old, Ca Mau Province Tra Vinh province

Collection time: 2018

In the study about ceremonial folk songs in traditional wedding of the Southern Khmer [9], the author detailed that:

\begin{abstract}
"The images appearing in the folk songs at the wedding of the Khmer people in the South are imbued with agricultural culture. The paintings of villages with familiar images can be seen on the wedding day such as: thorn hedges, Peây ponds, corkwood trees, village roads with all kinds of fruits and vegetables: pineapple, mangosteen, sapodilla plum, durian, mango, banana, papaya, betel nut, wine, pork, vegetables... they are used as the betrothal gifts; with the living tools: coconut shells, blankets, mats, pillows, and the ways of life of the villagers: bathing in ponds, scooping water with coconut shells. All of these are products made by the Khmer, simple but full of love".
\end{abstract}

Fourth, traditional music of Southern Khmer expresses family affection, love of couples, wishes and aspirations for a bountiful harvest, a happy and well-fed Phum, Soc; sincere feelings between men and women, beautiful natural scenery through sweet melodies and lyrics.

Based on the results of surveying the artisans and artists in Southern Vietnam, the researcher determined the structure of Southern Khmer folk music including the genres of folk songs, and traditional orchestras which are being practiced in the Southern Khmer community. Survey results have indicated that: there are $3 / 7$ genres of folk songs still existing in the daily life of Khmer people in the provinces and cities of the South, namely: ritual songs, Chom-Rieng-Cha-Pay, and Lullaby (Bom pê). The genres of work songs, Dong-Dao (Bot Chom riêng Kômara Kômarây), educational songs (Chbăp), and love songs are at risk of disappearing; there are 3/12 instrumental orchestras existing: Five-tone orchestra (Pin Peat), Kh'se orchestra and Chhay-Yam orchestra. Orchestras that have gradually disappeared in the cultural life of the Southern Khmer community, including: Kong Skor, Chapey Dang Veng, Arak, Mohori, Robam, Du ke (performed at Khmer pagodas) Yike, Sko thum, Khlong Khek. The results show the fact that the cultural and artistic life of the Khmer in the South is being affected by the changes of globalization context. Folk songs which are practiced in the working environment, and Dong-Daos which are performed by children in folk games, they are gradually disappeared in Khmer community activities because the practitioners are mainly young people, most of whom left the countryside to work in urban areas, in industrial zones, or children, they are almost no longer interested in folk games but mainly entertain themselves with video games or watch game shows on the mass media. The orchestras are at risk of disappearing mainly belong to ritual music, which are used in rituals of traditional society such as Neakta worshiping ceremony, Arak god worshiping ceremony, Moon worshiping ceremony, ancestor worshiping of the Robam and Du ke stage... with the sacred songs, and dances, they are performed in the above-mentioned ritual ceremonies. However, with the changes in cultue of modern society, the gradual decrease of the rituals, 
Volume 9 Issue 7 July 2021

the role of ritual music and sacred dances in the above mentioned ritual ceremonies have being lost over time.

\subsection{The transmition of Khmer traditional music in Southern Vietnam}

\subsubsection{Transmitting through the form of} training and teaching Khmer traditional music

Tra Vinh University is the only institution in Vietnam that performs the national key task of training human resources in Southern Khmer language - culture - art. Since 2012, the major of Traditional Instruments Performance (specialized in Performing Southern Khmer Traditional Instruments) has been trained at Tra Vinh University with college and university levels. However, the total number of students studying this major at the school is low and tends to decrease over the years. From 2012 to 2019, eight training courses were provided, the total number of registered students was only 29 . The number of students in 2012, 2013, 2014, 2015, 2016, 2017, 2018 and 2019 are respectively: 10, 07, 03, 02, 01, 02, 02 and 02. Despite many encouragement policies such as full scholarships, free-of-charge accommodation at the University's Dormitory, monthly stipend of 450,000 VND (10 months/school year) and other preferential regimes according to current regulations of the State, very few students enroll in this major or many students drop out before graduation.

In addition, many organizations and individuals have organized refresher courses, short-term training courses or learning-by-doing classes such as: Traditional instruments performance (Khmer five-tone orchestra) intermediate level at Soc Trang Intermediate School of Culture and Arts; classes for training Du ke performers and musicians at Tra Vinh Intermediate School of Culture and Arts in recent years, or held by Soc Trang Khmer Art Troupe in collaboration with Soc Trang Intermediate School of Culture and Arts in 2008; The Department of Culture, Sports and Tourism of An Giang Province, in 2014, organized a course in Chapey instrument for talented Khmer youths who are passionate about their ethnic art, taught by artisan Chau Nung and artisan Chau Hunh, who lived in O Lam commune, Tri Ton district, An Giang province. With the financial support from the locality, artist Danh Trung Hieu (Hai Thuol), in Ban Tan Dinh commune, Giong Rieng district,
Kien Giang province opened courses in the Fivetone Orchestra for more than 380 learners. Hau Giang province also provided courses in basic performance methods of A-day singing. Outstanding artist Tran Van Xen in Hoa Thanh district, Tay Ninh province has opened Chhay-Yam drum dance courses for many generations; the project of Reconstructing and Teaching Yeak Rom - Robam ballet of Southern Khmer, in 2013, implemented by the Department of Gender and Ethnicity, Tra Vinh University with the sponsorship of the Ford Foundation, $20 \mathrm{Khmer}$ youths in Giong Luc hamlet, Chau Thanh district, Tra Vinh province were chosen to be the participants.

It could be said that thanks to the strong support, encouragement and investment of the State in many aspects, the training and teaching of human resources in the field of Khmer art in Southern Vietnam has significantly developed in both quality and quantity in recent years. However, the survey results also indicated that the number of students studying at university level at training institutions, especially such number at Tra Vinh University is very small and decreasing over the years, while the training courses are taught at artists' or artisans' houses receiving a large number of participants. Thus, the activity of transmitting traditional music through the form of training and teaching is still mainly performed spontaneously by the Southern Khmer community, based on their own personal experiences.

\subsubsection{Transmitting through mass media and art festivals, competitions}

Since 2010, in an effort to preserve and spread the Khmer traditional music in the lives of ethnic groups inhabiting in Southern Vietnam, many organizations and individuals have deployed many activities with different forms such as: organizing art competitions, festivals, performances; radio and television programs in Khmer language; organizing activities in clubs, art troupes... In 2013, the Vietnam Theater Artists Association coordinated with the People's Committee of Soc Trang province to organize the "First Southern Khmer Du ke Theater art Festival". In 2018, the "First Mekong Delta Khmer folk song festival" was organized by the coordination of the Ethnic Language Television Department of Vietnam Television and Soc Trang Radio and Television, in Soc Trang province. Radio and television stations, including VTV5, Soc 
Volume 9 Issue 7 July 2021

Trang Radio and Television, Tra Vinh Radio and Television, Kien Giang Radio and Television... constantly produce and broadcast programs in Khmer language, thereby, many genres of Southern Khmer folk music have been being recorded and music activities regularly. The organization of national-scale competitions and festivals contributes to introducing the uniqueness of Southern Khmer folk music to the public at home and abroad. Furthermore, this is also an opportunity for artists to meet and exchange experiences in order to preserve and promote the traditional art form of the Khmer ethnic group, contributing to upholding culture, beauty and human values, the solidarity and friendship among ethnic groups. shown to meet the needs of people. In addition, many ethnic minority boarding schools in the provinces/cities of Mekong Delta region, where Khmer students account for a large number, also organize Southern Khmer folk In order to evaluate the effectiveness of forms of preserving and spreading Southern Khmer folk music in the community, the researcher conducted a questionnaire survey with the question: "According to you, by what means is Southern Khmer folk music effectively transmitted at present?" Table 2 describes the results in detail.

Table 2. Forms of spreading Southern Khmer folk music

\begin{tabular}{|l|c|c|}
\hline \multicolumn{1}{|c|}{ Forms of spreading } & Number & Proportion (\%) \\
\hline Television stations & 192 & 15.2 \\
\hline Art troupes, teams, groups, art clubs & 171 & 13.5 \\
\hline Radio stations & 163 & 12.9 \\
\hline Types of tapes, discs & 128 & 10.2 \\
\hline Art training and researching institutions & 127 & 9.1 \\
\hline Individuals, families & 114 & 8.2 \\
\hline Ethnic minority boarding schools & 103 & 7.9 \\
\hline Social networking sites & 100 & 7.5 \\
\hline Paper documents & 95 & $\mathbf{1 0 0}$ \\
\hline Types of electronic newspapers & 69 & \\
\hline
\end{tabular}

(Source: Summary of survey results, 2019)

It is found that, from the results in Table 2, the highly effective transmission form of Southern Khmer traditional music is through the mass media, including television stations; radio stations; tapes and discs; social networking sites and electronic newspapers with a rate of $51.7 \%$ compared to the traditional forms of transmission, which are from individuals, families and Khmer art troupes, teams, groups and clubs accounting for the proportion of $22.5 \%$, or from art training and researching institutions, ethnic minority boarding schools, and paper documents with the rate of $25.8 \%$. The results are also consistent with the actual situation of today society, when the mass media is increasingly popular and becomes the main and favorite form of entertainment of the ethnic 
Volume 9 Issue 7 July 2021

communities in southern Vietnam in general, and the Khmer in particular. From survey results in Table 2, in addition, the form of transmitting Khmer traditional music through the activities of art troupes and teams, art performances and competitions, which receive the investment from the state budget and high expectations of the community, still exist some certain limitations. Firstly, the provinces and cities have organized competitions and performances, but the effectiveness is still low and the quality is not high. The formality is also expressed through the organization of these activities. Competitions and performances have not attracted a large number of audiences. Some familiar troupes and clubs in the localities are still the main subjects participating in such activities. The nature of tradition in organizing cultural festivals is not high. Secondly, although the Southern region of Vietnam currently has five professional Khmer art troupes with the support and investment of the State, but the quality of some performances, the choreography and staging of new performances every year are still low. The repertoire performed by art troupes still lacks innovation in content and form, so it has not met the diverse and increasing aesthetic demands of the public. In addtion, the survey in the localities also shown the fact that, although the Khmer people in the South have a high demand for learning ethnic music, the art troupes have enough facilities, but no troupe has organized the training for Khmer people. The organization of training and vocational training mostly takes place on a small, sporadic and spontaneous scale.

\subsubsection{Transmitting through the form of collecting and researching}

The collection and research of Southern Khmer folk songs and musical instruments have been carried out from the $1970 \mathrm{~s}$ to $1990 \mathrm{~s}$ of the $20^{\text {th }}$ century.

Firstly, Southern Khmer folk songs have been collected and introduced in a variety of works, including Southern folk songs (1978) by Lu Nhat $\mathrm{Vu}$ and associates [10], Hau Giang folk songs (1986) by Le Giang and associates [11], Cuu Long folk songs (1986) by $\mathrm{Lu}$ Nhat $\mathrm{Vu}$ and associates [12], Kien Giang folk Songs (1985) by Lu Nhat Vu and associates [13], Song Be folk songs (1991) by Lu Nhat Vu and associates [14], Tra Vinh folk songs (2004) by Nguyen Truc Phong, Lu Nhat Vu, Nguyen Van Hoa, and Le Giang [15]. From the $21^{\text {st }}$ century, there have been many works on collection, selection and introduction of the folk literature of Southern ethnic groups. In particular, at a certain degree, Southern Khmer folk songs have been introduced in a number of works such as Bac Lieu folk literature (2011) by Chu Xuan Dien [16] and the latest collection of 100 Khmer folk tunes (2004) collected by Nguyen Van Hoa [17]. The total number of 328 Southern Khmer folk songs were collected and published. Specifically, there were 50 folk songs from the Southeast region and 298 ones from the Southwest region. Such Khmer folk songs were mainly related to the genres of lullaby (Bom pe), ritual songs, Du ke, Yike, Dong-Dao (BotChrieng-Komara-Komaray), educational songs (Chbap), love songs, etc. Many authors composed Southern Khmer folk songs under musical notes and in Vietnamese version. However, the collected folk songs do not fully cover the full picture of the Khmer Southern folk music. In particular, the authors have not mentioned the field of Khmer musical instruments in the South. According to statistics conducted from February to August 1999 by the Institute of Music, the Khmer, Cham and Hoa ethnic groups have 919 folk songs and 667 folk tunes, the Kinh people have 8,977 folk songs and 2,055 folk tunes, ethnic minorities in Truong Son - Central Highlands have 1,529 folk songs and 1,374 folk tunes, ethnic minorities in the North and North Central regions have 5,466 folk songs [18]. This shows that the collection and research of folk songs and folk tunes of the Khmer are still limited compared to other ethnic groups in Vietnam.

Secondly, there are outstanding achievements in the practice of collecting and researching Southern Khmer musical instruments, especially the studies conducted by Pham Duy [19], Le Ngoc Canh [20], Nguyen Thi My Liem [21]. Son Ngoc Hoang et al. [22]-[23], Hoang Tuc [24], etc. Particularly, the two most important works are Khmer folk musical instruments in the South [22] and Khmer folk musical instruments in Soc Trang [23]. Each musical instrument of the Southern Khmer has been specifically classified and described through such important works. The achievements related to the collection and research of folk songs and musical instruments can be regarded as a valuable and necessary source of document for researching, teaching and training Southern Khmer folk music nowadays as well as in the future. However, these works face some limitations. Firstly, the statistics, classification and identification of Southern Khmer 
Volume 9 Issue 7 July 2021

folk music genres have not been systematically implemented without scientific and practical evidences. In addition, there are still some mistakes relevant to translating into Vietnamese and making music notes of some folk songs and folk tunes because of certain difficulties during the process of translating from Khmer into Vietnamese.

\subsection{Recommendations for the preservation and promotion of Southern Khmer traditional music in the context of globalization}

Along with different music genres of more than 50 ethnic minorities, Southern Khmer traditional music has made certain contributions to the diversity and unity of Vietnamese culture. In the current context of international integration, there are important solutions for preserving and promoting the values of Southern Khmer folk music as follows:

Firstly, it is significant to make the effective system of policies and laws for encouraging organizations and individuals to participate in the preservation and promotion the values of Southern Khmer folk music. In particular, it is necessary to have a policy for honoring talented artisans as well as artists who have remarkably contributed to the values of Southern Khmer folk music. It is believed that the number of artists of Southern Khmer folk music in particular and other ethnic groups in Vietnam in general are limited and even gradually turn to zero. They have been preserving the national cultural heritage which will disappear if they die. Therefore, there should be more attention to the policies related to awarding, honoring and creating opportunities for artisans to promote their role in the cultural life of the community.

Secondly, it is important to inform and educate people in order to improve their awareness and responsibility in preserving and promoting the cultural values of Southern Khmer folk music. At the same time, there should be activities related to training, teaching, and restoring different genres of Southern Khmer folk music. With limited funds, the State should spend great efforts on the investment in restoring and teaching several unpopular music genres such as Chom-rieng, Chapay, Dong-Dao, lullaby, educational singing, Chapay-Doong-veng, or Arak Orchestra.
Thirdly, it is effective to use communication technology for promoting and educating Southern Khmer folk music. In the current context of globalization, medias play an important role in preserving and promoting the values of Southern Khmer folk music. In fact, printed and online newspapers, magazines, radio, television, books, Internet, etc. can work well in informing as well as transmitting the values of Southern Khmer folk music to the community, which is proved by the survey results. However, there is limited amount of time for introducing as well as honoring Vietnamese folklore in general and the cultural heritage of ethnic minorities in particular on medias. Actually, the allotted time of programs on Southern Khmer folk music is much less than that of other entertainment programs. Therefore, staff of Radio and Television Station should closely cooperate in choosing suitable contents and methods for preserving and promoting the cultural values of Southern Khmer folk music.

Finally, localities should cooperate with institutes or organizations to collect, study and translate folk music works into other languages such as Vietnamese and English. This will help to introduce Southern Khmer folk music to national and international communities.

\section{CONCLUSION}

The trend of globalization, Western culture and art, people's lack of awareness on traditional music, especially the young Khmer's limited awareness have negatively influenced the practice of Southern Khmer traditional music. In fact, the traditional music is not as popular as before and even gradually disappears. On the other hand, there is limited attention to educating folk music for the young Khmer. Besides, artisans of folk music are getting older. The number of artisans is more limited without successors. As a result, traditional folk songs without the written version have not been transmitted appropriately. A number of traditional ethnic musical instruments have been damaged and lost. Additionally, it is very difficult to make ethnic musical instruments because of limited number of knowledgeable artisans for teaching the youth. Therefore, at present, there are a few places such as the culture galleries of Tra Vinh and Soc Trang preserving some traditional musical instruments. Such important instruments are no longer used in social life. The above mentioned issues are regarded as causes of 
Volume 9 Issue 7 July 2021

disappearance and inappropriate preservation of Southern Khmer traditional musical instruments. Therefore, the Khmer are facing certain difficulties in enjoying traditional folk music.

Nowadays, it is urgent to put scientific solutions into practice in order to preserve and promote the folk music heritage of the Southern Khmer. These important solutions are believed to satisfy the Southern Khmer's need of cultural enjoyment. Especially, the preservation and promotion of the values of Southern Khmer folk music remarkably contribute to the preservation of Southern Khmer national identity. The recommended solutions help to preserve the essential values and to promote the cultural values of morality, lifestyle, aesthetics and education in the Khmer community.

\section{REFERENCES}

[1]. Committee for Ethnic Minority Affairs General Statistics Office of Vietnam, "Survey results on collecting information about the reality of socio-economic of 53 ethnic minorities in 2019" (Kết quả điều tra thu thập thông tin về thực trạng kinh tế - xã hội của 53 dân tộc thiểu số năm 2019), Ha Noi, Vietnam: Statistics Publishing House, 2020, p. 54.

[2]. Dao Chuong, "Southern Khmer folk music in the time before and now" (Âm nhạc dân gian Khmer Nam Bộ trước đây và hiện nay), Report at Scientific Conference: Southern Khmer folk music - Theoretical issues and experiences, Tra Vinh University, Vietnam. 2018.

[3]. Son Ngoc Hoang, "Current situation of researching, collecting and teaching of Khmer folk musical instruments in the South of Vietnam" (Thực trạng nghiên cứu, sưu tầm và truyền dạy nhạc khí dân gian Khmer Nam Bộ), Proceedings of the Scientific Conference: Preserving and promoting cultural values of Khmer folk music in the South - Current situation and solutions, Tra Vinh University, Vietnam, 2019, pp. 16-25.

[4]. Pham Tiet Khanh, "Situation of research on Khmer folk music in the South" (Tình hình nghiên cứu trong và ngoài nước về âm nhạc dân gian Khmer Nam Bộ), Culture and Art Magazine (Vietnam), No. 6(420): pp. 85-88, 2019.

[5]. Francesca Billeri, "The process pf reconstruction and revival of musical heritage in contemporary Campuchia", Moussons, No. 30: pp. 91-109, 2017.

[6]. Pham Tiet Khanh, Nguyen Dang Hai and Pham Thi To Thy, "The situation of preservation and promotion of the cultural values of Khmer folk music in the South of Vietnam", The Scientific Journal of Tra Vinh University, 2019, No. 35: pp. 9-21. DOI: 10.35382/18594816.1.35.2019.198.

[7]. Thach $\mathrm{Mu} \mathrm{Ni}$, "The relationship between conservation and development, between tradition and modernity, between identity and reception in Southern Khmer folk music in the current context" (Mối quan hệ giữa bảo tồn và phát triển, giữa truyền thống và hiện đại, giữa bản sắc và tiếp nhận trong âm nhạc dân gian Khmer Nam Bộ trong bối cảnh hiện nay), Proceedings of the Scientific Conference: Preserving and promoting cultural values of Khmer folk music in the South - Current situation and solutions, Tra Vinh University, Vietnam, 2019, pp. 41-45.

[8]. Duong Hoang Loc, Bui Huu Nghia, Duong Anh Thy, "Folk performances of Southern Khmer people: characteristics and preservation solutions" (Diễn xướng dân gian tộc người Khmer Nam Bộ: đặc điểm và một số giải pháp bảo tồn), Proceedings of the Scientific Conference: Preserving and promoting cultural values of Khmer folk music in the South - Current situation and solutions, Tra Vinh University, Vietnam, 2019.

[9]. Pham Tiet Khanh, "Ritual folk songs in the traditional wedding of Southern Khmer people" (Dân ca nghi lễ trong đám cưới truyền thống của người Khmer Nam Bộ). Journal of Folk Culture (Vietnam), No. 5(155), 2014.

[10]. Lu Nhat Vu, Le Giang, Nguyen Van Hoa, "Southern folk songs" (Dân ca Nam Bộ). Ho Chi Minh City, Vietnam: Arts Publishing House, 1978. [11]. Lu Nhat Vu, Le Giang, Nguyen Van Hoa, Minh Luan, "Hau Giang Folk songs" (Dân ca Hậu Giang). Hau Giang Department of Culture and Information, Vietnam, 1986.

[12]. Lu Nhat Vu, Nguyen Van Hoa, Le Giang, Thach Han, "Cuu Long folk songs" (Dân ca Cửu Long), Cuu Long Department of Culture and Information, Vietnam, 1986.

[13]. Lu Nhat Vu, Nguyen Van Hoa, Le Giang, "Kien Giang folk songs" (Dân ca Kiên Giang). Kien Giang Department of Culture and Information, Vietnam, 1985.

[14]. Lu Nhat Vu, Nguyen Van Hoa, Le Giang, Tu Nguyen Thach, "Song Be folk songs" (Dân ca Sông Bé). Song Be, Vietnam: Song Be General Publishing House, 1985.

[15]. Nguyen Truc Phong, Lu Nhat Vu, Nguyen Van Hoa, Le Giang, "Tra Vinh folk songs" (Dân ca 
Volume 9 Issue 7 July 2021

Trà Vinh), Tra Vinh Department of Culture and Information, Vietnam, 2004.

[16]. Chu Xuan Dien (Ed), "Bac Lieu folklore" (Văn học dân gian Bạc Liêu), Ha Noi, Vietnam: Hanoi National University Publishing House, 2011. [17]. Nguyen Van Hoa (collect), "100 Khmer folk tunes" (100 làn điệu dân ca Khmer), Ho Chi Minh City, Vietnam: Tre Publishing House.

[18]. Phuong Thao, "Scientific conference on the statistical work of traditional music heritage" (Hội thảo khoa học về công tác thống kê vốn di sản âm nhạc cổ truyền), Nhan dan Newspaper (Nhân dân diện tử), (17/9/2010), Retrive from: https://www.nhandan.com.vn/vanhoa/dongchay/item/4196202-.html [retrive date: 19/3/2018]. [19]. Pham Duy, "Monograph on folk music in Vietnam" (Đặc khảo về dân nhạc ở Việt Nam), Sai Gon, Vietnam: Hien Dai Publishing House, 1972. [20]. Le Ngoc Canh, "Southern Khmer tratitional music" (Nghệ thuật âm nhạc truyền thống Khmer
Nam Bộ), Journal of Art and Culture (Vietnam), 2004, p. 5.

[21]. Nguyen Thi My Liem, “Textbook of Vietnam traditional music" (Giáo trình âm nhạc truyền thống Việt Nam), Ha Noi, Vietnam: Music Publishing House, 2014.

[22]. Son Ngoc Hoang, Dao Huy Huyen, Ngo Khi, "Southern Khmer folk musical instruments" (Nhạc khí dân tộc Khmer Nam Bộ), Ha Noi, Vietnam: Social Sciences Publishing House, 2005.

[23]. Son Ngoc Hoang, Dao Huy Huyen, Ngo Khi, Soc Trang Khmer folk musical instruments (Nhạc khí dân tộc Khmer Sóc Trăng), Ho Chi Minh city, Vietnam: Ho Chi Minh City General Publish House, 2007.

[24]. Hoang Tuc, "Southern Khmer folk song performances" (Diễn ca Khmer Nam Bộ), Ho Chi Minh City, Vietnam: Thoi Dai Publishing House, 2011. 